Article

\title{
What Makes Me Want You Here? Refugee Integration in a Zambian Settlement Setting
}

\author{
Steven Gronau* and Brigitte Ruesink \\ Institute for Environmental Economics and World Trade, Leibniz University Hannover, \\ 30167 Hannover, Germany; ruesink@iuw.uni-hannover.de \\ * Correspondence: gronau@iuw.uni-hannover.de; Tel.: +49-511-762-19966
}

\begin{abstract}
Many of the world's refugees remain in Africa, where they stay long-term, mainly in neighboring countries. The present directions point to integration, in which the host society and the political surroundings play a key role. This paper aims to investigate the ways in which public opinion towards and contact with refugees support integration processes. We apply this research to a settlement setting in rural Zambia, a recent dataset of 275 households from 2018, and an econometric analysis. This is the first study dealing with a set of factors that affect the hosts' opinion towards and contact with refugees in an African settlement context, and with respect to the Comprehensive Refugee Response Framework produced by the United Nations. Our results show, particularly, the religiosity, group membership, life satisfaction, food insecurity, agricultural ownership and natural resource uses of the host society to be the main factors that need policy consideration for the promotion of refugee integration. Stakeholders dealing in host-refugee settings and seeking for durable solutions should roll out community programs to address threat perceptions and interaction improvements.
\end{abstract}

check for

updates

Citation: Gronau, S.; Ruesink, B. What Makes Me Want You Here? Refugee Integration in a Zambian Settlement Setting. Sustainability 2021, 13, 8380. https://doi.org/10.3390/ su13158380

Academic Editor: Nick Drydakis

Received: 22 June 2021

Accepted: 22 July 2021

Published: 27 July 2021

Publisher's Note: MDPI stays neutral with regard to jurisdictional claims in published maps and institutional affiliations.

Copyright: (c) 2021 by the authors. Licensee MDPI, Basel, Switzerland. This article is an open access article distributed under the terms and conditions of the Creative Commons Attribution (CC BY) license (https:// creativecommons.org/licenses/by/ $4.0 /)$.
Keywords: integration; inclusion; refugees; host society; opinion; contact; Africa

\section{Introduction}

The current numbers of refugees are at a global peak. Worldwide, 26 million people are living as refugees resulting from persecution, conflict, violence, human rights violations, or events seriously disturbing public order. The headlines predominantly highlight the implications of the refugee crisis in European, North American and Australian destinations, but in reality, 8 out of 10 refugees remain in lower-income countries bordering conflict zones [1]. Africa, the poorest continent in the world, hosts approximately $34 \%$ of all refugees. According to the current estimates, a large proportion lives in about 800 camps on the continent [2]. These are often located in very poor areas where the inhabitants themselves struggle to make a living [3].

For a long time, refugee policies had an emergency aid character, caring for refugees in camps and aiming to send them home or to third countries as fast as possible [4]. The intention was that they would stay short-term [5]. However, the short-term perspective seems increasingly less relevant [6]. Many refugees spend years to decades in camps, and children grow up without knowing any other home [7]. The average length of displacement ranges between 10 and 15 years, but can even exceed 20 years [8]. It is thus extremely unlikely that people will return to their country of origin or resettle in a third country soon [5], which is also proven by the vanishingly small rates of repatriation and resettlement [1]. However, as scholars note [4,5,9-12] and recent United Nations High Commissioner for Refugees (UNHCR) policy shift reflects [1], the local integration of refugees into host societies represents a durable solution and an increasingly popular strategy.

Central aspects of integration are the host society's public opinion and the contact between hosts and refugees $[7,13]$, which both shape and are shaped by governmental policies $[6,11,14]$. Globally, a number of public opinion surveys document a mixed picture 
of attitudes towards immigrants. An Ipsos MORI poll [15] showed views on the refugee crisis across 25 countries. In South Africa, the majority of the respondents are uncomfortable with current levels of immigration, and nearly half are less confident that they will successfully integrate. In line with the more negative view is an International Organization for Migration (IOM) poll [16] that drew on data from 142 countries. In sub-Saharan African countries, around half of the respondents want immigration levels to decrease. Whitaker and Giersch [17] support these findings by using survey data from 11 countries in sub-Saharan Africa, which generally shows high rates of anti-immigration and a rising xenophobic sentiment. However, Dempster and Hargrave's [18] comprehensive review on public attitudes towards refugees highlights that encouraging contact between local and immigrant populations is essential. More contact might have the benefit of fostering greater community openness towards refugees [19], which promotes local integration [9].

Immigration policies, at multiple levels, influence the context to be more or less welcoming $[7,18,20]$, and thus affect integration $[1,14,20,21]$. Less-inclusive integration policies are associated with more negative attitudes towards immigrants, and limitations to host-refugee contact undermine integration efforts [6]. Inclusive immigration policies in Africa are driven by the idea of a unified Africa and the positive effects of integration on economic development [22]. Currently, the UNHCR wants to move towards an "alternativeto-camps" policy [5]. In adopting the New York Declaration for Refugees and Migrants in September 2016, the 193 UN member states agreed upon core elements of a Comprehensive Refugee Response Framework (CRRF), and to work towards the adoption of a Global Compact on Refugees (GCR). Integration into national development plans is essential for both the host communities and refugees, and is consistent with the pledge to "leave no one behind" in the 2030 Agenda for Sustainable Development. The CRRF aims to support the countries and societies that host a large number of refugees, promote their inclusion into host communities, involve development actors and develop a "whole-of-society" approach (www.unhcr.org accessed on 4 June 2021). In essence, local integration is a key element. By now, several African countries, including Chad, Djibouti, Ethiopia, Kenya, Rwanda, Somalia, Uganda and Zambia, have implemented the CRRF [10,23]. However, because the CRRF is at an early stage, there is need for research on the policy approach and its implications in facilitating local integration [5].

The issue of refugee integration has probably never been more important, but research on the role of host societies in supporting integration is insufficient [20]. There is little analysis on how to move residents into more integrated refugee relationships [5]. In particular, better knowledge of the public opinion and host-refugee contact potentially assists local integration as a viable policy option [11]. Hence, we need to better understand the attitude towards refugees within host societies [19] and the conditions in which they interact [24], especially in smaller communities where the likelihood of interaction is higher [6].

We address the research needs by investigating the ways in which public opinion towards and contact with refugees supports integration processes in an African host society. In particular, the paper raises the following two questions: (1) What are the driving forces of hosts' opinions towards refugees? (2) Which factors affect host communities' contact with refugees? Our quantitative research approach incorporates a bivariate probit model approach and takes advantage of recent survey data from 275 Zambian households from April 2018.

Our analysis focuses on a host society in Zambia, which receives considerable immigrant inflows from the Democratic Republic of Congo (DRC). In late 2017, northern Zambia, in particular, became an immigration hotspot as thousands of Congolese crossed the border with minimal prospects of return to the fragile state. In response to the Congolese refugee emergency, the Zambian government set up a settlement, called the "Mantapala settlement", rolled out the CRRF in November 2017 and designed a national roadmap towards a "whole-of-society" approach. Of particular note, this was the first time a government adopted the CRRF from the onset of a settlement establishment, seeking for a 
durable solution and local integration, and engaging all relevant ministries [25]. The pilot character of the Mantapala policy also attracted a recent visit by the UNHCR, from Mr. Filippo Grandi, in October 2019. The Commissioner met various regional and local stakeholders to discuss the CRRF in the Mantapala community [26]. The integrative policy approach, recent refugee movements from the DRC and the subsequent settlement construction in a Zambian host society-a recurring and historical migration story between the two countries-followed by sustainable development considerations provide a suitable context to study this topic.

Our research contributes to the scientific literature via the quantitative analysis of a set of common and novel factors that are important for opinion formation and human interactions to promote refugee integration into African host societies. For this purpose, we examined the European and African-specific literature and added the characteristics of the study site. To the best of our knowledge, it is the first study that investigates the topic in a Zambian settlement setting. The scientific analysis points to specific factors that need (political) attention to foster host-refugee integration processes. Finally, within the scope of the CRRF of the United Nations, the study even has a pilot character. Following the introduction of our research paper, we review the existing literature on the integration of, public opinion towards and contact with immigrants, primarily from European, North American and Australian contexts. The next chapter contains the research area and describes the data collection. Theoretical approaches provide the foundation of the conceptual framework, followed by an explanation of the unique set of factors for analysis and the quantitative model approach. Our results section highlights the key outcomes of the factors affecting public opinion towards and contact with refugees. It also discusses the scientific literature, and connects findings to societal integration processes and state key policy messages. Finally, the paper concludes and provides an outlook for future research.

\section{Literature Review}

Integration is a broad concept and has no single definition [9]. In a model of refugee integration for developing countries, Kuhlman [14] particularly emphasized the host-related factors of the settlement region, economic participation, and local, regional and national immigration policies, including those by the UNHCR. Similarly, Ager and Strang [27] provided a framework that considers the ways in which policy affects the process of integration. The main elements are social connections between host community members and refugees, equal access to opportunities and resources, and participation in the society. Penninx and Garcès-Mascareñas [28] (p. 11) summarized: "The term integration refers to the process of settlement, interaction with the host society, and social change that follows immigration." Finally, in policy terms, local integration is a dynamic and two-way process, i.e., refugee adaptation and host country openness. For effective integration, institutions at local and national levels, as well as local communities, need to proactively promote social cohesion [1].

Researchers predominantly identify public opinion as a central aspect of effective refugee integration into new host societies $[6,7,29]$. A common view in the relevant scientific literature on public opinion is that immigrants, and refugees more specifically, pose a threat to members of a host community, whether merely perceived or real $[24,30,31]$. Following the integrated threat theory $[32,33]$, concerns of threat are a key element in attitudes towards refugees. It proposes that prejudice and intergroup conflict emerge when members of a group feel danger from an outgroup $[34,35]$. The feeling may stem from diverse factors such as the relative size of the minority group [36,37], associations of violence and crime [31,38], concerns regarding security [39-41], a change of cultural values and norms [42,43], the spread of infectious diseases [44] and the risk of higher food insecurity [11,45]. Fears that immigrants will be an economic burden are also prevalent [7,11], with those perceiving higher threats reporting less support for the hosting of refugees [31,46]. The concerns relate to competition for employment $[4,47]$, low levels of economic development and rising unemployment [48]. Hellmann et al. [13] used the example of eastern and western Germany, 
and stated that higher unemployment rates and the fear of competition for resources and economic opportunities with outgroup individuals translate into a higher perceived threat, i.e., negative attitudes. Herreros and Criado [29] used different individual-level and country-level variables to explain the attitudes towards immigration in 16 European countries. Most notably, economic satisfaction decreases the opposition to migration. Perceptions of threat are thus influenced by one's own vulnerability, and are greater among individuals in more difficult economic conditions $[7,49]$.

Contact and interactions between host society members and refugees are further key elements of successful integration $[9,21,42,50]$. Based on contact theory [51,52], intergroup contact under appropriate conditions reduces prejudice and conflict between majority and minority groups. Pettigrew and Tropp's [53] meta-analysis of 515 studies of contact theory found that greater intergroup contact is consistently associated with lower levels of prejudice, regardless of the specific intention of the interaction. In an Australian study, the respondents stated that meeting a refugee influenced their opinion towards asylum seekers mostly positively [31]. Similarly, a study by Crawley et al. [54] in a British context concluded that opportunities for meaningful social contact with immigrants are a key factor for the formation of a positive attitude. However, not only contact influences opinion; it can also be an interplay $[40,42]$. Generally, the literature suggest that contact theory works best when it applies to everyday activities [18]. In particular, the labor and goods markets offer potential for host-refugee interactions [11,55]. A meaningful effect on labor markets is the direct competition, but also the cooperation between locals and refugees [4,47]. The African context shows that agricultural workers suffer from fiercer competition, whereas producers (self-employed farmers and host businesses) benefit from the presence of refugees due to the additional supply of cheap labor $[3,56]$. Further arenas for exposure are marketplaces in African camps [12,57]. Vemuru et al. [58] highlighted trade and meetings in markets as one of the most important forms of social interaction for hosts and refugees. A further possible conflict area is the natural resource base in settlement surroundings, i.e., the competition for scarce natural resources between local communities and refugees [41]. Drawing on data from 5 refugee camps in Ghana, Agblorti and Grant [9] found that over half of the host-refugee conflicts between 2003 and 2014 related to the use of environmental resources, such as cutting trees for fuelwood and charcoal.

\section{Materials and Methods}

\subsection{Study Site and Data Collection}

Zambia plays an important role in providing refuge for displaced persons from the fragile DRC. Recurring security issues in late 2017 caused thousands of Congolese to cross the northern Zambian border to seek protection. A quickly established transit center provided initial shelter, but was only a temporary solution. As a result of the continuous population influx, the Zambian government decided, in early 2018, to establish the "Mantapala settlement" for relocation. The DRC and Zambia share a long history, including mine worker migration from Northern Rhodesia (Zambia) to Katanga (DRC) in the early 20th century [59] and Congolese seeking refuge in Zambia because of the Congo wars [60], but also as a result of ongoing conflicts [61]. Finally, some Zambians even have their family roots in Congo [62]. Zambia's role in hosting refugees is of very high significance today and in the future [63].

The study site, Mantapala, is situated in the Nchelenge District, which marks the boundary to the DRC (Figure 1). It is located very remotely in a forest area, about $20 \mathrm{~km}$ from the nearest small town, Nchelenge, and over $1000 \mathrm{~km}$ from the capital, Lusaka. A gravel road is the only way in and out, indicating the poor local infrastructure. Food insecurity and malnutrition heavily affect Zambia [64], and the rural poverty rate is nearly $80 \%$ [65]. This also reflects the living conditions in the study area, which are marked by severe poverty and food insecurity [66,67]. Agriculture, especially, plays a prominent role in the Nchelenge district [68]. Households' livelihoods in Mantapala are mainly based on subsistence agriculture and forest resource extraction (nearly $90 \%$ of the village GDP). 
Typically, farmers cultivate low-yield cassava and maize next to groundnuts, beans, sweet potato, rice and millet on 1 to 3 hectares of land. Firewood and charcoal constitute the households' main energy sources, as the majority live in traditional huts with no electricity connection. In addition, marginal fish stocks from a nearby river and some streams provide a source of food. Besides this, many households keep small livestock [69]. See the Figure 1.
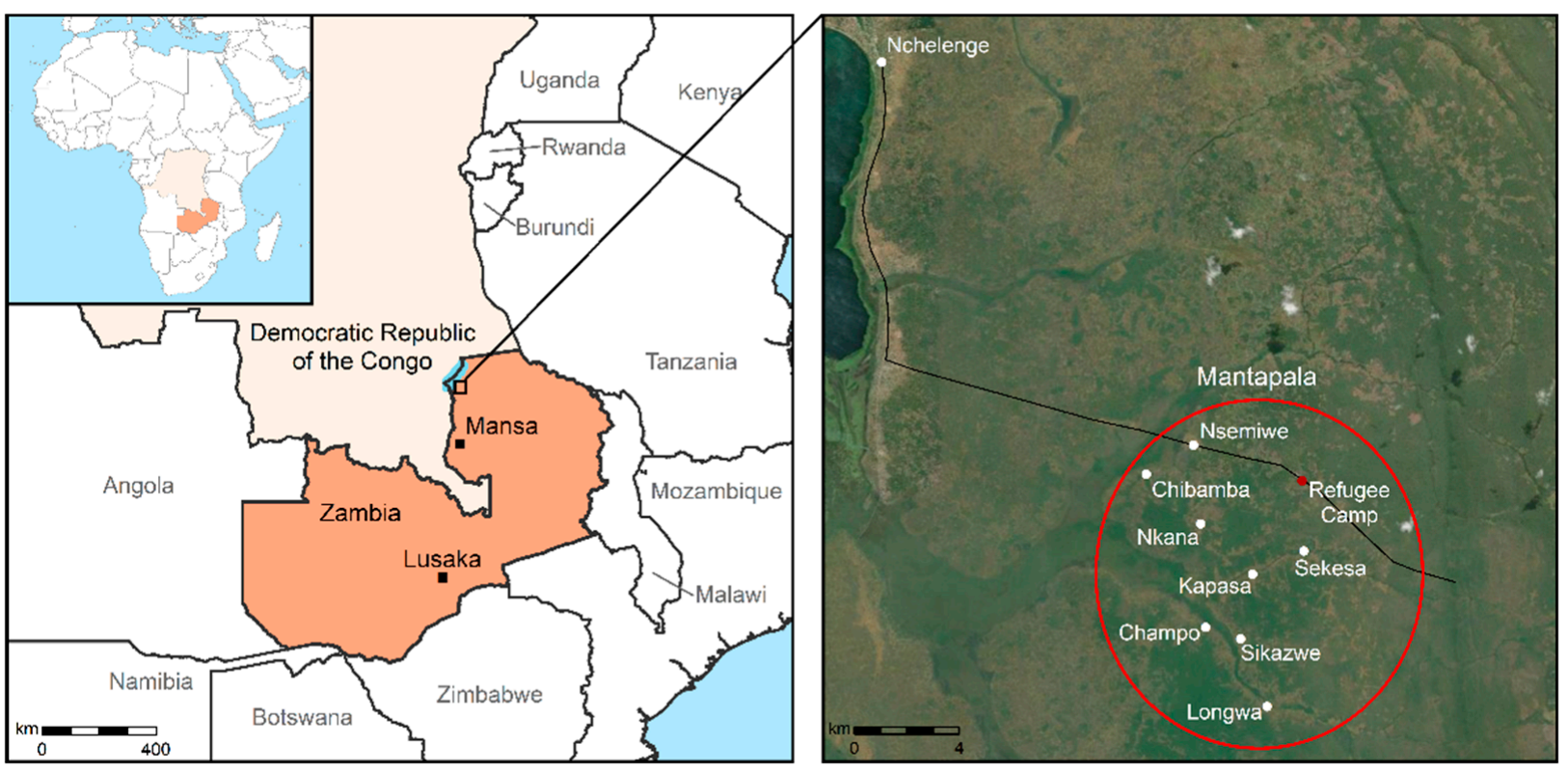

Figure 1. Host-refugee society in Zambia.

The exemplary Zambian settlement setting is located within a rural host society of 275 households (1659 residents) from 8 villages. Each village comprises about 10 to 80 households within a radius of 9 kilometers around the Mantapala settlement. Its proximity is favorable for the analysis, as the scientific literature suggests a 10-kilometer radius to cover potential host-refugee interactions [12,57] and the main markets where refugees transact [56]. In total, the Mantapala area covers about 13,000 hectares [69]. Around 8000 hectares relate to the settlement, which accommodates about 15,231 Congolese [70]. Hence, the settlement occupies more than half of the study area, and the host-refugee ratio is approximately 1 to 10 .

Zambia provides a favorable policy environment for refugee integration into host societies. The country follows international conventions on the rights of refugees and asylum seekers, and the UN 2030 Agenda to "leave no one behind". This is based on the National Development Plan (2017-2021) and the Refugee Act 2017. The new domestic act established the legal pillar for the protection of asylum seekers, and enabled the socio-economic integration of refugees in the country, which represents a significant shift from the 1970 Refugee Control Act. The Office of the Commissioner for Refugees in the Ministry of Home Affairs is responsible for refugee settlements in Zambia. In addition, the country collaborates with UNHCR and UN agencies to achieve sustainable solutions for host-refugee communities in line with the "Sustainable Development Goals" [70]. In November 2017, the Zambian government rolled out the CRRF [25]. The CRRF in Zambia aims to (1) locally integrate Congolese and other refugees; (2) relax the encampment policy by permission to leave a settlement; (3) enhance access to work and income generating activities; (4) provide education for children in settlements; and (5) ensure refugees' opportunities for civil registration and other legal documents [10]. Today, Zambia is host to 81,776 refugees residing mainly in 3 settlements: Mayukwayukwa and Meheba, which have existed for more than 5 decades and underline the long history of the country in hosting refugees, and Mantapala, which is the most recent and only settlement in northern Zambia [71]. International organizations like FAO, UNICEF, WHO and WFP support 
the Luapula province in response to the Congolese refugee influx in 2017. This is complemented by several countries' donations, the European Union, the Central Emergency Response Fund and private donors [72].

There are already initial links between hosts and refugees in the study region. For instance, locals find off-farm employment in the settlement (e.g., administration, construction, guarding), hosts employ refugees as farm workers, and cash/food assistance and farm land allocations to every refugee household (for residential use and farming) enable trade interactions. However, heavy deforestation as a result of the settlement's development and competition for scarce natural resources seems to be an increasing problem. In addition, host and refugee households jointly participate in economic support programs like rainfed agriculture, gardening, small livestock and business start-up grants, and interact at a market with over 200 traders in the Mantapala settlement. Finally, it has two schools where host and refugee children learn alongside one another, and both parties use a collective health facility.

Our paper takes advantage of a recent household survey dataset of 275 households collected in April 2018. It is based on four-week field research (1 week of survey training and 3 weeks of data collection), as part of the "Food Security in Rural Zambia (FoSeZa)" project funded by the German Federal Ministry of Food and Agriculture, see Gronau et al. [66] for more project information. The dataset covers all of the households (census) from the 8 villages of the Mantapala host society. We conducted a structured questionnaire with the respective household head. It included questions on the household's socio-demographics, social capital, economic activities, income sources, savings, consumption and expenditures, use of natural resources, livestock breeding, agricultural production, land uses, and food security. The questionnaire also comprised a section on the Mantapala refugee settlement, containing questions on public opinion towards and contact with refugees. The respondents also indicated the respective area of contact. The section concluded with a question on life satisfaction. The recall period of the survey was the 12 months between April 2017 and March 2018.

\subsection{Determining Factors}

According to the scientific literature and theoretical foundations, Figure 2 shows our conceptual framework. Refugee integration into a host society is paramount. It is based on a country's policy setting. Our analysis focused on public opinion and contact, which are key components of integration. These elements interrelate and depend on a range of factors. We applied a unique set of 15 factors. This includes a number of common variables from the European and African-specific literature, such as age, education and the distance to a camp. The other determinants are novel and of particular importance in the Zambian host community, including food access, land and livestock ownership, and fish and firewood use. We organized the set of factors into four groups: individual, household, agriculture and natural resource.

The two main components of our quantitative model analysis were (1) public opinion towards and (2) contact with refugees. We measured the dependent (outcome) variables using two binary (yes/no) questions: (1) "Do you think refugees in Mantapala impact your daily life?" and (2) "Do you have contact or an experience with a refugee in Mantapala?" The keyword "think" is common in the investigation of public opinion and attitudes in an immigration context $[16,17,73]$, but researchers also use proxies such as "hire a refugee", "allow child to marry a refugee" [19] or "agreement to stay in the country" [54]. Contact means that a survey respondent has/had a real-life experience with a refugee at a particular area of contact. This relates to natural resource spots, security issues, education participation/schools, joint employment, the health center and trade at the market. Similarly, Çirakoğlu et al. [40] assessed the level of contact in a host-refugee setting via a list of possible contact places. 


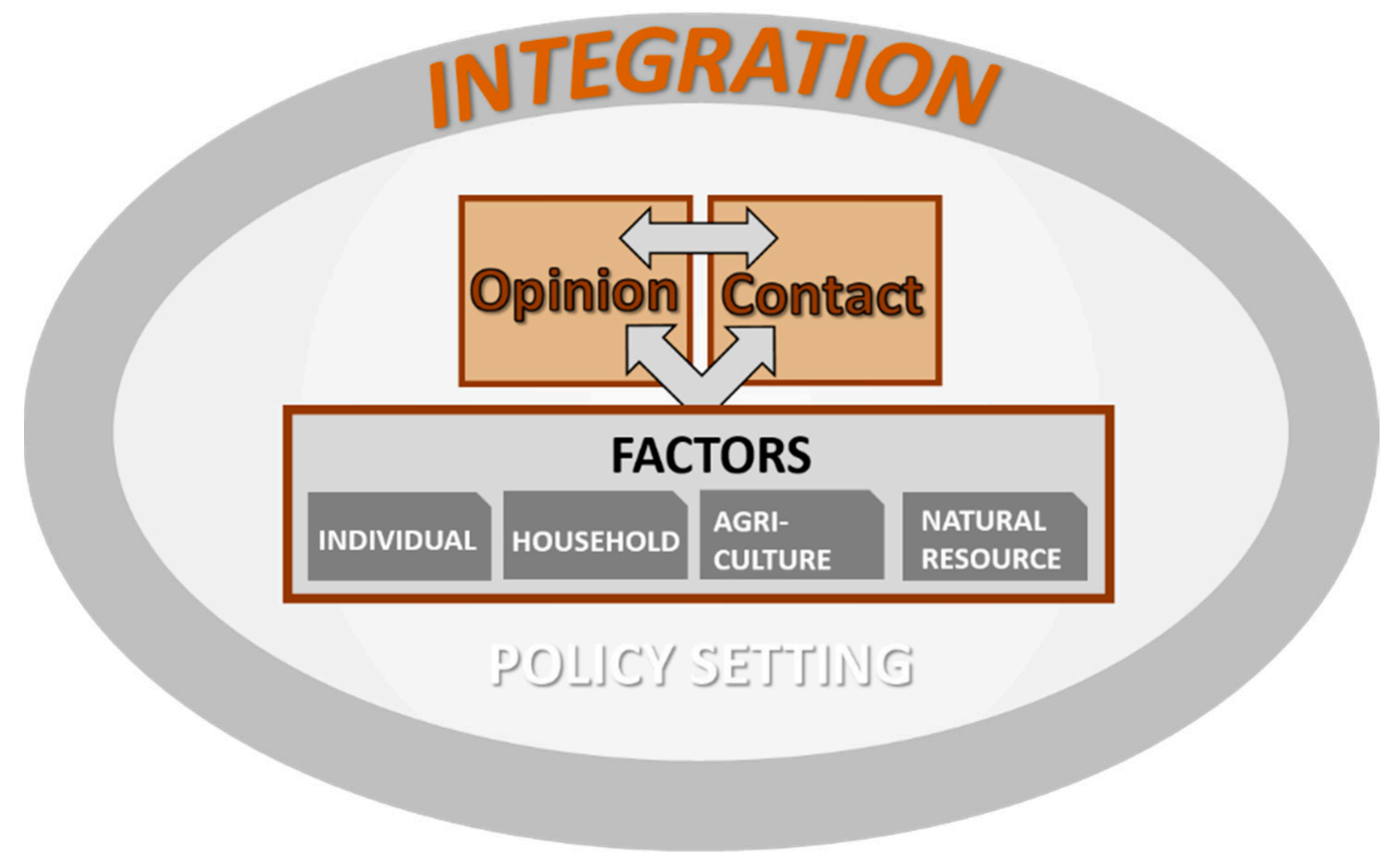

Figure 2. Conceptual framework on integration, opinion and contact.

We identified a unique set of 15 factors to explore hosts' opinions and contact in the rural society. Table 1 gives an overview of the independent (explanatory) variables. The first category, respondents' individual characteristics, includes age, education, gender, religion, group membership and social contact variables. Religion is a binary variable (protestant or not). We considered social capital via group membership (activity in a communitybased group) and social contact (important people/close friends outside the household). The second category, household characteristics, constitutes size, savings, distance to the settlement, life satisfaction and food access. Savings are a proxy for financial status. Because poverty dominates the study site, the implementation of a common income variable [19] is not meaningful. We approximated life satisfaction (three-point scale: worse, same, better) via the survey question: "How do you perceive the well-being of your household compared to one year ago?" This is particularly interesting because the Mantapala refugee settlement did not exist a year ago. Similarly, McLaren [42] evaluated life satisfaction via respondents' perceptions of whether their personal conditions have improved or become worse compared to 5 years ago. We paid special attention to the inclusion of a food access variable, which has not yet been applied as a determining factor for refugee integration. We measured food access via the food security indicator "Months of Adequate Household Food Provisioning". A value of one indicated that a household had enough food in each month of the last year. In addition, a number of site-specific agriculture and natural resource variables added value to the existing research. The third category describes agricultural characteristics, i.e., land ownership for farm production and livestock possession (tropical livestock units (TLU)). According to Bundervoet [74], TLU is the sum of a households' weighted animals according to their size (ranging from 0.01 for rabbits to 1.0 for cattle). The land and livestock variables are also proxies for rural households' financial status [75]. Finally, the fourth category defines natural resource characteristics. Fish and firewood are essential livelihood components for rural communities [76,77]. This is why we included a binary variable for catching fish and collecting firewood. 
Table 1. Overview of factors (independent variables).

\begin{tabular}{|c|c|c|c|}
\hline Variable & Definition & Scale & Reference \\
\hline \multicolumn{4}{|l|}{ Individual characteristics } \\
\hline Age & Respondent's age & Metric, in categories & \multirow{3}{*}[19,24,42,43,73]{} \\
\hline Education & Respondent's educational level & Metric, in categories & \\
\hline Gender & Respondent's gender & Binary, female $=1$ & \\
\hline Religion & Respondent's religion & Binary, protestant $=1$ & {$[19,54,78]$} \\
\hline Group member & Respondent's group membership & Binary, membership = 1 & \multirow{2}{*}{ [55] } \\
\hline Social contacts & Respondent's number of contacts & Binary, at least 2 contacts $=1$ & \\
\hline \multicolumn{4}{|l|}{ Household characteristics } \\
\hline Size & Household size & Metric, in members & {$[54,79]$} \\
\hline Savings & Household's total savings & Metric, in dollar & {$[19,24,42,43,73]$} \\
\hline Distance & Household's camp proximity & Metric, in categories & {$[12,55,57]$} \\
\hline Life satisfaction & $\begin{array}{l}\text { Perception of well-being } \\
\text { compared to one year ago }\end{array}$ & Metric, in categories & {$[29,42,43]$} \\
\hline Food access & $\begin{array}{l}\text { Months of adequate household } \\
\text { food provisioning }\end{array}$ & Binary, 12 months food = 1 & Own identification \\
\hline \multicolumn{4}{|l|}{ Agricultural characteristics } \\
\hline Land size & Household's total land ownership & Metric, in ha & \multirow[b]{2}{*}{ Own identification } \\
\hline Livestock possession & Household's number of livestock & Metric, in TLU & \\
\hline \multicolumn{4}{|c|}{ Natural resource characteristics } \\
\hline Fish catch & Household's fish catch & Binary, yes = 1 & \multirow{2}{*}{ Own identification } \\
\hline Firewood collection & Household's firewood collection & Binary, yes $=1$ & \\
\hline
\end{tabular}

\subsection{Examining Relationships}

In an initial model approximation, we applied two separate probit models to estimate the propensity scores for the opinion and contact outcomes. This is an appropriate approach for binary dependent variables where the relationship between the dependent and independent variables follows a cumulative density function of the normal distribution [80]. Equations (1) and (2) show the probability for an opinion towards and contact with refugees. At this point, the outcome variable of one model is independent in the regression of the other. Our 15 explanatory variables $\left(\mathrm{x}_{\mathrm{i}}\right)$ were categorized into individual, household, agricultural and natural resource characteristics. We define the probit models as follows:

$$
\begin{gathered}
\mathrm{P}\left(\text { opinion }=1 \mid \mathrm{x}_{\mathrm{i}}\right)= \\
\Phi\left(\alpha_{0}+\alpha_{1} \text { contact }_{\mathrm{i}}+\alpha_{2} \text { individual }_{\mathrm{i}}+\alpha_{3} \text { household }_{\mathrm{i}}+\alpha_{4} \text { agriculture }_{\mathrm{i}}+\alpha_{5} \text { nat.res }_{\cdot \mathrm{i}}+\varepsilon\right), \\
\mathrm{P}\left(\text { contact }=1 \mid \mathrm{x}_{\mathrm{i}}\right)= \\
\Phi\left(\beta_{0}+\beta_{1} \text { opinion }_{\mathrm{i}}+\beta_{2} \text { individual }_{\mathrm{i}}+\beta_{3} \text { household }_{\mathrm{i}}+\beta_{4} \text { agriculture }_{\mathrm{i}}+\beta_{5} \text { nat.res. }_{\mathrm{i}}+\varepsilon\right) .
\end{gathered}
$$

In accordance with scientific literature $[40,42,53]$ and the conceptual framework, our probit model outcomes confirmed a strong relationship between public opinion and contact, revealing high significances and a notable correlation (0.193). According to Rayton [81], a bivariate probit model tests whether or not a model's fit improves through the joint analysis of two independent variables. It relaxes the assumption of independence that is implicit in the standard (binomial) probit model. In particular, Greene [82] specified a bivariate probit model approach to investigate two related variables. The specification is as follows:

$$
\begin{gathered}
Y_{1}^{*}=x_{1}^{\prime} \beta_{1}+\varepsilon_{1}, Y_{1}=1 \text { if } Y_{1}^{*}>0,0 \text { otherwise, } \\
Y_{2}^{*}=x_{2}^{\prime} \beta_{2}+\varepsilon_{2}, Y_{2}=1 \text { if } Y_{2}^{*}>0,0 \text { otherwise, } \\
E\left(\varepsilon_{1} \mid x_{1}, x_{2}\right)=E\left(\varepsilon_{2} \mid x_{1} x_{2}\right)=0, \\
\operatorname{Var}\left(\varepsilon_{1} \mid x_{1}, x_{2}\right)=\operatorname{Var}\left(\varepsilon_{2} \mid x_{1} x_{2}\right)=1,
\end{gathered}
$$




$$
\operatorname{Cov}\left(\varepsilon_{1}, \varepsilon_{2} \mid \mathrm{x}_{1}, \mathrm{x}_{2}\right)=\rho
$$

As part of the model specification, we moved from the two separate probit models and checked for a bivariate probit model application. $Y_{1}^{*}$ and $Y_{2}^{*}$ are the dependent variables "public opinion" and "contact". The actual outcome of $Y_{1}$ and $Y_{2}$ is equal to one if the unobservable variables $Y_{1}^{*}$ and $Y_{2}^{*}$ are above zero. These conditions reflect the ways in which individuals with different characteristics may still come to the same opinion/contact, but some more easily than others. The vectors $x_{1}^{\prime}$ and $x_{2}^{\prime}$ define the independent variables, and the vectors $\beta_{1}$ and $\beta_{2}$ are the corresponding coefficients, which we estimated via the maximum likelihood method [83]. The expected value given to $x_{1}$ and $x_{2}$ for the error terms $\varepsilon_{1}$ and $\varepsilon_{2}$ is zero, and the assumed variance is equal to one. The parameter of key interest is the covariance of the error terms $(\rho)$, which is based on the difference between a separate probit model and a bivariate probit model approach. Value $\rho$ measures the suitability of a bivariate probit model: (a) if $\rho$ is equal zero, it is unnecessary and more appropriate to use two separate probit models. (b) If $\rho$ is unequal to zero (=correlated error terms), there is a relationship between Equations (3) and (4) that the independent variables do not explain. Consequently, a bivariate probit model is straightforward, and the application of two individual probit models leads to biased results [81]. Given that the bivariate probit model considers the interdependency of the two dependent variables, it addresses the problem of endogeneity between opinion and contact. Finally, the Wald test is a method to check for a zero correlation between the error terms and therefore the independence of the two components $\left(Y_{1}^{*}\right.$ and $\left.Y_{2}^{*}\right)$ of a bivariate probit model $[82,84]$. Our Wald test rejected the null-hypothesis $(\rho=0)$ and confirms a bivariate probit model application.

In the final stage of the bivariate probit model's application, we tested for heteroscedasticity, robustness and multicollinearity. First, because of the heteroscedastic nature of the microeconomic data in bivariate probit models [83], we controlled for heteroscedasticity via the inclusion of robust standard errors. Second, the in/exclusion and/or change of explanatory variables did not alter the outcomes significantly, indicating a robust model, see Morais et al. [85], which included alternative country-specific variables as a robustness test. Third, the Variance Inflation Factor (VIF) tests for multicollinearity [86]. Finally, we determined the statistical significance of our estimates by inspecting the $p$-values, with rates of $0.1,0.05$ and 0.01 indicating significance-levels at $10 \%, 5 \%$ and $1 \%$. In order to examine which factors influence the hosts' probability of having an opinion about or contact with refugees, we used Stata IC 14 for our econometric analysis.

\section{Results and Discussion}

\subsection{Interrelation of Opinion and Contact}

Our model evaluation revealed a number of meaningful results regarding the host societies' opinion towards and contact with refugees in the Zambian settlement setting. Most importantly, 3 in 4 host community members had an opinion on refugees, and 9 out of 10 have/had contact with refugees. Contact areas are natural resource spots, security issues, education participation/schools, joint employment, the health center and trade at the market. Our bivariate probit model application confirmed a strong relationship between opinion and contact. The positive correlation parameter was significant $(\rho=1.050$; $p<0.005)$, i.e., having contact increases the hosts' probability of having an opinion about the refugees. Table 2 provides background information on the sample characteristics. Below, we highlight main findings related to individual, household, agricultural and natural resource factors (Table 3), whether significant or not, and discuss possible policy implications. 
Table 2. Sample characteristics.

\begin{tabular}{|c|c|c|c|c|}
\hline Variable & Scale & Obs. & Mean & SD \\
\hline \multicolumn{5}{|l|}{ Key observations } \\
\hline Public opinion: impact daily life & $\%$, yes & 275 & 0.77 & 0.42 \\
\hline Contact: real-life experience & $\%$, yes & 275 & 0.93 & 0.25 \\
\hline \multicolumn{5}{|l|}{ Individual characteristics } \\
\hline Age & years & 275 & 42.54 & 14.59 \\
\hline Age 15-29 & $\%$ & 20.36 & 1 & 0 \\
\hline Age 30-54 & $\%$ & 58.55 & 2 & 0 \\
\hline Age $>54$ & $\%$ & 21.09 & 3 & 0 \\
\hline Education & years & 275 & 6.66 & 2.97 \\
\hline No education & $\%$ & 5.09 & 0 & 0 \\
\hline Primary education & $\%$ & 55.27 & 1 & 0 \\
\hline Secondary/higher education & $\%$ & 39.64 & 2 & 0 \\
\hline Gender & $\%$, female & 275 & 0.20 & 0.40 \\
\hline Religion & $\%$, protestant & 275 & 0.74 & 0.44 \\
\hline Group member & $\%$, yes & 275 & 0.36 & 0.48 \\
\hline Social contacts & no. & 275 & 1.67 & 0.92 \\
\hline Social contacts (at least 2) & $\%$ & 275 & 0.46 & 0.50 \\
\hline \multicolumn{5}{|l|}{ Household characteristics } \\
\hline Size & members & 275 & 6.03 & 2.37 \\
\hline Savings & dollar & 275 & 27.74 & 43.83 \\
\hline Distance & $\mathrm{km}$ & 275 & 4.80 & 1.59 \\
\hline $\begin{array}{l}\text { Immediate distance (adjacent to } \\
\text { camp) }\end{array}$ & $\%$ & 20.00 & 1 & 0 \\
\hline Short distance $(<5 \mathrm{~km})$ & $\%$ & 46.18 & 2 & 0 \\
\hline Medium distance $(>5 \mathrm{~km})$ & $\%$ & 21.82 & 3 & 0 \\
\hline $\begin{array}{c}\text { Long distance }(>5 \mathrm{~km} \text { and beyond } \\
\text { river) }\end{array}$ & $\%$ & 12.00 & 4 & 0 \\
\hline Worse life satisfaction & $\%$ & 33.09 & 1 & 0 \\
\hline Same life satisfaction & $\%$ & 27.64 & 2 & 0 \\
\hline Better life satisfaction & $\%$ & 39.27 & 3 & 0 \\
\hline Food access & $\%$, yes & 275 & 0.42 & 0.50 \\
\hline Months of enough food & months & 275 & 10.36 & 2.58 \\
\hline \multicolumn{5}{|l|}{ Agricultural characteristics } \\
\hline Land size & hectare & 275 & 6.73 & 5.64 \\
\hline Livestock possession & TLU & 275 & 0.61 & 1.17 \\
\hline \multicolumn{5}{|l|}{ Natural resource characteristics } \\
\hline Fish catch & $\%$, yes & 275 & 0.30 & 0.46 \\
\hline Firewood collection & $\%$, yes & 275 & 0.85 & 0.36 \\
\hline
\end{tabular}

Obs., observations. SD, standard deviations. No., number.

\subsection{Results and Discussion of the Factors of Opinion and Contact}

\subsubsection{Individual Characteristics}

Interestingly, the respondents' education and age are not significant factors for their opinion towards refugees ("thinks refugees impact daily life"), but are relevant for contact with immigrants ("real-life experience"). Having a primary education increases the probability of host-refugee interactions, but older respondents (age $>54$ ) are less likely to connect with outsiders (Table 3). The outcomes possibly reflect peoples' social and economic (in-)activity with respect to their education and age. According to the scientific literature, hosts with higher levels of education are often in a stronger economic position and feel less threat [54,79]. They are more adaptive to the changing situation in a settlement setting [11], for example through trade [12] and collaborative employment [3]. Additionally, more educated and younger individuals tend to hold positive views towards immigration [31], whereas older people's views are rather negative [54]. In order to promote integration, 
policy interventions at the study site can target the education of younger residents to increase host-refugee interactions.

Table 3. Results of the bivariate probit model for opinion and contact.

\begin{tabular}{|c|c|c|c|c|}
\hline \multirow[t]{2}{*}{ Dependent Variables } & \multicolumn{2}{|c|}{$\begin{array}{c}\text { (1) } \\
\text { Public Opinion }\end{array}$} & \multicolumn{2}{|c|}{$\begin{array}{c}(2) \\
\text { Contact }\end{array}$} \\
\hline & Mean & SE & Mean & SE \\
\hline \multicolumn{5}{|l|}{ Individual characteristics } \\
\hline Age 15-29 & 0 & . & 0 & . \\
\hline Age 30-54 & -0.343 & 0.288 & -0.118 & 0.321 \\
\hline Age $>54$ & -0.200 & 0.335 & $-0.722 *$ & 0.316 \\
\hline No education & 0 & . & 0 & . \\
\hline Primary education & -0.465 & 0.425 & $0.809 *$ & 0.387 \\
\hline Secondary/higher education & -0.186 & 0.430 & 0.724 & 0.435 \\
\hline Gender & 0.146 & 0.247 & -0.274 & 0.255 \\
\hline Religion & 0.531 * & 0.218 & 0.023 & 0.300 \\
\hline Group member & $0.486 *$ & 0.218 & 0.202 & 0.264 \\
\hline Social contacts & 0.203 & 0.193 & -0.039 & 0.245 \\
\hline \multicolumn{5}{|l|}{ Household characteristics } \\
\hline Size & -0.001 & 0.049 & -0.005 & 0.052 \\
\hline Savings $(\ln )$ & $-0.072 *$ & 0.033 & -0.003 & 0.038 \\
\hline Immediate distance & 0.356 & 0.255 & 0.068 & 0.325 \\
\hline Short distance & 0 & . & 0 & . \\
\hline Medium distance & 0.116 & 0.244 & -0.074 & 0.292 \\
\hline Long distance & 0.173 & 0.305 & $-0.725^{*}$ & 0.298 \\
\hline Worse life satisfaction & $-0.961 * * *$ & 0.247 & 0.222 & 0.283 \\
\hline Same life satisfaction & 0 & . & 0 & . \\
\hline Better life satisfaction & -0.091 & 0.266 & $0.730 *$ & 0.306 \\
\hline Food access & $-0.440 *$ & 0.191 & 0.368 & 0.281 \\
\hline \multicolumn{5}{|l|}{ Agricultural characteristics } \\
\hline Land size $(\ln )$ & $-0.281 *$ & 0.113 & -0.045 & 0.095 \\
\hline Livestock possession $(\ln )$ & $0.143 *$ & 0.060 & -0.090 & 0.068 \\
\hline \multicolumn{5}{|l|}{ Natural resource characteristics } \\
\hline Fish catch & 0.182 & 0.207 & 0.010 & 0.270 \\
\hline Firewood collection & 0.139 & 0.290 & -0.442 & 0.349 \\
\hline Constant & $1.827^{* *}$ & 0.689 & $1.150 *$ & 0.565 \\
\hline \multicolumn{5}{|l|}{ AtRho } \\
\hline Constant & $1.050^{* * *}$ & 0.313 & & \\
\hline Observations & 275 & & & \\
\hline
\end{tabular}

* Significant at $10 \%,{ }^{* *}$ significant at $5 \%,{ }^{* * *}$ significant at $1 \%$; SE, robust standard error.

Religion has a positive influence on hosts' opinion. Protestant respondents (74\% of the sample) had a higher probability of an attitude towards refugees than individuals with another religion. We interpreted that immigration issues have already been addressed in their church, but it does not seem to be a place to meet/interact with community strangers. According to Unser and Ziebertz [78], attention for people in need is a central theme in the Christian tradition, which generally encourages its believers to be open to strangers. The Congolese are predominantly Christian, i.e., protestant or catholic [4], possibly minimizing the residents' anxiety about losing a religious majority status. Alternatively, it can be the other way round. The significant effect of the religion variable reflects hosts' fears of losing their protestant majority status, as Congolese are predominantly Catholic, especially in the Katanga province bordering Zambia [87]. Anyway, at the decision-making level in the study area, it seems relevant to consider hosts' religiosity and church communications, but also the religion of the refugees. Gender-specific policies to support refugee integration do not appear necessary. 
The hosts' social capital, i.e., group membership and social contacts, shows differing results in our impact analysis. While group membership has a significant effect on the formation of an opinion, the number of friends is not significant at all. The sample characteristics show that a third are members of a community-based group (agriculture, health, commune council, microfinance), and 50\% have at least 2 important social contacts (close friends). We thus confirmed the sparse social network at the study site [67]. However, according to Fajth et al. [55], social networks indicate an individual's level of engagement, connection, cooperation and active participation in the community, and Phillimore [20] emphasized its potential to support refugee integration processes. The significance of group membership for having an opinion illustrates the potential of groups for integration processes in the study area. It confirms that hosts are more likely to discuss the refugee context and corresponding fears and opportunities in groups. This is reasonable, as community groups focus on topics where refugee settlement developments have large impacts on, e.g., labor competition or additional labor force availability in agriculture [3]. We conclude that group membership reveals a promising potential to target host community fears, support sustainable development opportunities and finally create more contact (e.g., joint group formations).

\subsubsection{Household Characteristics}

The size of the household was not a significant factor in our analysis, but households' savings impact the formation of an opinion towards refugees. In a European country context, Rustenbach [79] stated that individuals with children may be more interested in the future of their society. Translated to the rural study site, we would expect household heads to observe developments in their neighborhood with caution in order to preserve a culturally and economically stable future for the next generation. Households' savings lower the likelihood of an attitude towards refugees, which we relate to a feeling of more security. Households with savings do not perceive a threat from a changing environment as strongly as households without. Our result is consistent with the scientific literature, indicating that threat perceptions are greater among those with lower economic status [7,49]. The amount of savings of a household is not significant for contact, which is surprising, as higher amounts of money enable economic opportunities. Policy interventions at the study site can address potential knowledge gaps in business development by financially stronger households, with inherent integration processes (e.g., via labor cooperation). Household size seems irrelevant in the refugee integration context.

Regarding households' proximity to the settlement, there is no relationship to the formation of an opinion, but a significant effect on contact with refugees. From a mindset perspective, we suppose human thoughts on a camp development next door. Our result is similar to that of Fajth et al. [55], indicating that household proximity $(<10 \mathrm{~km})$ is insignificant for the feeling of safety in Rwandan communities. From the perspective of real-life experience, we confirmed that households living farther away ( $>5 \mathrm{~km}$ and beyond a river) have a lower probability of contact with a refugee. This is consistent with Bilgili et al. [88], pointing to the dependence of physical proximity and possible contact in refugee camps in Rwanda. They associated the distance between refugees and hosts with more or less integration. For policy measures, we suggest the inclusion of households that are farther away from societal interaction points in integration interventions. This also links to the "whole-of-society" approach of the CRRF by the United Nations.

Households' life satisfaction shows interesting results for public opinion towards and contact with refugees. A host has a significantly lower probability of an attitude if he/she perceives the household's well-being to be worse than it was a year ago. We relate the result to the high poverty level at the study site, as a household in a difficult living situation likely has other concerns than immigration, and focuses primarily on itself (need to survive). We thus indicate a possible societal exclusion of vulnerable households. Inversely, the likelihood of refugee contact increases when hosts are more satisfied with their life. We interpret that households with a higher perceived wellbeing are more open to 
contact with outsiders. More specifically, an interaction with refugees can actually be the origin of a higher well-being. Our results relate in an interesting way to refugee research studies: Chambers [89] argued that the better-off hosts usually gain from the presence of refugees, while the poorer/vulnerable ones are the hidden losers. According to an IOM poll [16] in Africa, people with a lower perception about their standard of living are more negative towards immigration, and for European countries, economic satisfaction tends to decrease opposition to immigrants [29,43]. From a policy perspective, we should address poverty levels in rural refugee settings and push households into better living conditions (e.g., via joint community programs), potentially increasing host-refugee contact rates and thus promoting societal integration. In this way, poor host households are included in development processes.

A society's food security is an essential determinant for public opinion. The "Months of Adequate Household Food Provisioning" food security indicator shows an alarming result in the host community: about 6 out of 10 households suffered from insufficient food access (scarcity) in some month of the year. Our model results reveal that these food-insecure households have a significantly higher probability of the formation of an attitude. This implies that food-insecure households feel affected by immigrants' presence, either as threat to their livelihoods or hope for improvements. Contrary to this, households in a food-secure situation are more neutral towards refugees. The insignificance to contact is surprising, as interactions in the goods and labor market can link to hosts' nutrition [45]. One of the few studies about the refugee impact on food security is by Gengo et al. [90], which found that trade networks and employment opportunities in a Kenyan refugee camp surrounding have a positive effect on the hosts' nutritional status. In particular, food packages that refugees receive from aid organizations, mainly sold to or traded with residents, contribute to the local food supply [12]. Policy decisions towards refugee integration in the rural Zambian settlement setting need to consider the potential food insecurity of the host society. Critically, there is a contradiction with the life satisfaction variable (category: "perception of worse well-being compared to one year ago"). Our implication that this group of respondents may think less about the impact of refugees on their daily lives suggests that life satisfaction is not related to food, but implies other reasons (the death of the main breadwinner, serious injury, etc.).

\subsubsection{Agricultural Characteristics}

Interestingly, we found a significant relationship between households' land size and opinion. The hosts' land ownership lowers the probability of the formation of an attitude towards refugees; conversely, those with less land pay more attention. According to Agblorti and Grant [9], governments may take land from locals without negotiating the terms for acquisition and adequate compensation. As a result, land-receiving refugees face unhealthy relationships in the rural society from the very beginning. Our insignificant result on land size and contact reveals that host-refugee interactions on agricultural fields possibly play a minor/marginal role in the community at the moment. Given that every refugee household in Mantapala receives a land parcel from the government of the Republic of Zambia, see UNHCR [71], we expect the result to become significant in the future when land scarcity increases for the number of people living in the area. For integration interventions at the study site, land allocations to refugees primarily harm the host society members with less land ownership who need suitable compensation.

A further agricultural feature is households' livestock possession, which increases the likelihood of an opinion towards refugees. Households mainly keep small livestock, namely pigs, goats, chicken and/or ducks. Our result on attitude may relate to locals' fear of theft or the opportunity to sell the livestock and related products at the local market in the settlement [11]. We found no evidence for a connection between hosts' animal possession and the likelihood of contact with refugees. If policy interventions focus on livestock ownership to promote integration processes (locals and refugees currently receive 
economic support at the study site via small animals [10]), programs should either address households' fears of livestock theft or provide training on the generation of related benefits.

\subsubsection{Natural Resource Characteristics}

Surprisingly, our analysis revealed no relationship between the use of natural resources, i.e., fish and firewood, and the formation of an opinion towards and contact with refugees. Around a third of the host community catches fish from water stocks, and nearly all households require firewood from the forest. The results indicate that hosts do not have a particularly positive or negative attitude (e.g., threat perception) or considerable real-life experience (e.g., conflict situations at a natural resource spot). This contrasts the scientific evidence that highlights heightened environmental impacts caused by a settlement $[11,41]$ and increased competition for scarce natural resource between hosts and refugees $[9,58]$. The researchers particularly emphasize forest loss, i.e., deforestation, due to the development of a settlement $[2,91]$, which is already a severe problem at the study site [69]. However, our model results indicate that forest management concerns have little impact on whether the respondents pay attention to refugees in their daily lives. We relate the missing significance of natural resource competition to the assumption that the perception of scarcity has not yet exceeded the critical threshold across the whole study area's society. Nevertheless, policy interventions in settlement settings should take into account the maturity of a settlement in order to avoid future conflicts for natural resources, as fish and forest stocks may change over time. Furthermore, decision-makers should work to discover local hot spots before designing interventions. At the study site, there is no need to address fish and forest management, whereas land distribution is a much more pressing issue for integration purposes.

\section{Conclusions}

The paper aimed to explore the factors that affect hosts' opinions towards and contact with refugees in a Zambian settlement setting. We highlighted that refugees are not a short-term problem for the receiving country; rather, policy seeks societal integration. The United Nations' CRRF provides a possible policy approach for rural settlement settings. Most important to successful integration is the host society, which is mainly driven by two components: their opinion towards and contact with outsiders. For the quantitative analysis we identified a unique set of hosts' individual, household, agricultural and natural resource characteristics. These are common and novel factors that are important for opinion formation and human interactions from the European and African-specific literature, and also features of the study site. The quantitative analysis used a recent dataset from 2018 comprising 275 households of a rural refugee hosting community in Zambia, which is currently affected by considerable Congolese immigration inflows. We found a bivariate probit model to be the most suitable for the investigation. In particular, our research targeted (1) the driving forces of hosts' opinion towards refugees and (2) the factors affecting communities' contact with refugees.

Our results showed that the case study's host society perceives extensive mental and physical ties to refugees. The large majority of the community has an opinion towards and also contact with the outsiders. The interaction areas are natural resource spots, education participation/schools, joint employment, trade, the health center and security issues. In a nutshell, our scientific analysis pointed to 5 factors that need (political) attention to promote refugee integration into host societies in African, especially Zambian, settlement settings: (1) The hosts' opinion towards and contact with refugees are interrelated and crucial elements in a policy integration framework. (2) Religiosity is a significant factor in opinion formation, indicating the strong role of church communications in rural areas and the critical observation of strangers' beliefs. (3) Community-based groups in host societies have promising potential to counter the fears of hosts and improve their opinion about refugees and the related potential for sustainable development. (4) The critical investigation of hosts' life satisfaction, food insecurity and ownership of land and livestock is 
essential to integration approaches. (5) Surprisingly, natural resource uses are insignificant determinants, but in order to avoid potential future conflicts that would hinder integration processes, changes in the utilization and stock of fish and forest resources need observation.

From an implementation perspective, stakeholders dealing in host-refugee settings and seeking durable solutions can roll out community programs to address public opinion (threat perceptions) and contact (interaction improvements). There are a wide range of possible interventions in a host-refugee society, for example via joint participation in economic support programs (like gardening, small livestock and fishery) and mutual trainings to tackle shared livelihood threats (e.g., deforestation). Fair benefit distributions and common goals may alleviate social tensions. In addition, community places offer a space to meet, exchange and develop trust. Municipalities, NGOs and schools can organize events to give people the possibility to hear the true stories of individuals in real-contact conditions. Moreover, immigrant workshops are a means to teach the implicit and unwritten dimensions of a host society, including values, norms and hints for daily life. Another simple approach for host programs to promote integration is "imagined contact" [92]. Mentally stimulating a positive contact experience activates associations with successful interactions. This can create feelings of greater comfort and less fear of future contact, but does not replace real-life experiences. As a further implementation perspective, a survey of the local community should be conducted as part of the CRRF in order to ensure that policy makers do not limit themselves to "best practices", but rather focus on the real societal hot spots for integration.

There are some aspects of integration that our paper did not address. This concerns media representations, which can affect host attitudes towards outsiders $[30,40,46]$ and also the refugees themselves via language, skills, education, age, openness towards contact, and cultural adaptation $[21,31,47]$. It would also be interesting to include a trust indicator in such an integration analysis, given that European country studies show more positive attitudes towards immigration in societies with high levels of social trust see $[29,43,79]$. Our study also revealed interesting directions for further research. The extensive dataset was from the early stage of the settlement development in 2018, i.e., right at the beginning. An investigation of the mid-term impacts in the CRRF settlement setting would provide fruitful aspects for integration research and policy analysis. Especially, the progress indicated by UNCHR [71], e.g., including the support of rain-fed agriculture or grants for startup businesses, leads to the expectation of changing refugee-host relations in the near future. Furthermore, our quantitative model evaluated opinion and contact as binary outcome variables. Valuable model extensions would be a positive or negative rating of the attitudes, and an in-depth analysis of the interaction areas instead of the general analysis of contact. A further quantitative census, complemented by qualitative research tools, in the rural community would allow interesting scientific extensions and comparisons. Finally, a change in the independent variable composition reveals potential for alternative model applications.

Even though the analysis is specific to a Zambian context, it is (a) useful for research in comparable host-refugee settings that search for durable solutions, (b) applicable to other CRRF piloting countries or states that prepare for the policy approach, and (c) helpful for UNHCR interventions. The results help to identify the promoting and hindering factors of opinion and contact, and thus to define integration programs. Vice versa, the outcomes can assist immigrants in understanding host societies and thus the development of better integration strategies. Our paper provides an initial step in the research on hosts' opinions towards and contact with refugees to foster integration in African communities, and offers potential for future research.

The integration of refugees in host societies takes time. The challenge is to create a new community based on openness, tolerance and solidarity: 'Live and Let Live'. The normative framework of the CRRF provides a policy foundation towards more integrated host-refugee societies, and is subject to long-term processes. Integration interventions should involve all of the stakeholders, especially hosts and refugees. 
Author Contributions: Funding acquisition, investigation, project administration, supervision, writing-original draft, S.G.; formal analysis, methodology, software, B.R.; data curation, validation, visualization, writing-review and editing, S.G. and B.R. All authors have read and agreed to the published version of the manuscript.

Funding: This research was funded by the Leibniz Young Investigator Grant of the Leibniz University Hannover, Germany. Grant number LYIG-08-2019-11.

Institutional Review Board Statement: Not applicable.

Informed Consent Statement: Not applicable.

Data Availability Statement: The data presented in this study are available on request from the authors.

Acknowledgments: This article was written in the context of the Leibniz Young Investigator Grant by the Leibniz University Hannover (project: interrelations between refugee and host communities in rural Zambia) [LYIG-08-2019-11]. The dataset originates from the "FoSeZa-Food Security in rural Zambia" project, funded by the German Federal Ministry of Food and Agriculture (BMEL) [2813FSNU11]. Ethical clearance for the field research design was granted by the University of Zambia (UNZA). The publication of this article (article processing charge) was funded by the Open Access Fund of the Leibniz University Hannover. The authors want to thank the people living in Mantapala for their continuous support. They also thank the Zambian Ministry of Agriculture, the Ministry of Fisheries and Livestock, and the Zambia Agriculture Research Institute (ZARI) for field research assistance at the study site. They also thank Emilia for her feedback on the article.

Conflicts of Interest: The authors declare no conflict of interest. The funders had no role in the design of the study, in the collection, analyses, or interpretation of data, in the writing of the manuscript, or in the decision to publish the results.

\section{References}

1. UNHCR. Global Trends: Forced Displacement 2019; UNHCR: Copenhagen, Denmark, 2020.

2. Maystadt, J.-F.; Mueller, V.; van den Hoek, J.; van Weezel, S. Vegetation Changes Attributable to Refugees in Africa Coincide with Agricultural Deforestation. Environ. Res. Lett. 2020, 15. [CrossRef] [PubMed]

3. Maystadt, J.-F.; Verwimp, P. Winners and Losers among a Refugee-Hosting Population. Econ. Dev. Cult. Chang. 2014, 62, 769-809. [CrossRef]

4. Kreibaum, M. Their Suffering, Our Burden? How Congolese Refugees Affect the Ugandan Population. World Dev. 2016, 78, 262-287. [CrossRef]

5. Smith, L.; Howard, D.A.; Giordano, M.; Yossinger, N.S.; Kinne, L.; Martin, S.F. Local Integration and Shared Resource Management in Protracted Refugee Camps: Findings from a Study in the Horn of Africa. J. Refug. Stud. 2019. [CrossRef]

6. Hynie, M. Refugee Integration: Research and Policy. Peace Conflict J. Peace Psychol. 2018, 24, 265-276. [CrossRef]

7. Esses, V.M.; Hamilton, L.K.; Gaucher, D. The Global Refugee Crisis: Empirical Evidence and Policy Implications for Improving Public Attitudes and Facilitating Refugee Resettlement. Soc. Issues Policy Rev. 2017, 11, 78-123. [CrossRef]

8. Devictor, X.; Do, Q.-T. How Many Years Have Refugees Been in Exile? Popul. Dev. Rev. 2017, 43, 355-369. [CrossRef]

9. Agblorti, S.K.M.; Grant, M.R. Conceptualising Obstacles to Local Integration of Refugees in Ghana. Refug. Surv. Q. 2019, 38, 195-213. [CrossRef]

10. Carciotto, S.; Ferraro, F. Building Blocks and Challenges for the Implementation of the Global Compact on Refugees in Africa. J. Migr. Hum. Secur. 2020, 8, 83-95. [CrossRef]

11. Maystadt, J.-F.; Hirvonen, K.; Mabiso, A.; Vandercasteelen, J. Impacts of Hosting Forced Migrants in Poor Countries. Annu. Rev. Resour. Econ. 2019, 11, 439-459. [CrossRef]

12. Taylor, J.E.; Filipski, M.J.; Alloush, M.; Gupta, A.; Rojas Valdes, R.I.; Gonzalez-Estrada, E. Economic impact of refugees. Proc. Natl. Acad. Sci. USA 2016, 113, 7449-7453. [CrossRef]

13. Hellmann, J.H.; Forthmann, B.; Knausenberger, J.; Hellmann, D.F.; Rees, J.H.; Gansel, E.; Back, M.D.; Echterhoff, G. Support for Refugee Integration in West and East Germany: Results from two lost letter studies. Soc. Psychol. 2020, 51, 106-115. [CrossRef]

14. Kuhlman, T. The Economic Integration of Refugees in Developing Countries: A Research Model. J. Refug. Stud. 1991, 4, 1-20. [CrossRef]

15. Skinner, G.; Gottfried, G. Global Views on Immigration and the Refugee Crisis; IPSOS MORI: London, UK, 2017; Available online: https:/ / www.ipsos.com/en/global-views-immigration-and-refugee-crisis (accessed on 4 June 2021).

16. Esipova, N.; Ray, J.; Pugliese, A.; Tsabutashvili, D. How the World Views Migration; International Organization for Migration: Geneva, Switzerland, 2015.

17. Whitaker, B.E.; Giersch, J. Political Competition and Attitudes towards Immigration in Africa. J. Ethn. Migr. Stud. 2015, 41, 1536-1557. [CrossRef] 
18. Dempster, H.; Hargrave, K. Understanding Public Attitudes towards Refugees and Migrants; Overseas Development Institute: London, UK, 2017; Working Paper 512.

19. Ghosn, F.; Braithwaite, A.; Chu, T.S. Violence, displacement, contact, and attitudes toward hosting refugees. J. Peace Res. 2019, 56, 118-133. [CrossRef]

20. Phillimore, J. Refugee-integration-opportunity structures: Shifting the focus from refugees to context. J. Refug. Stud. 2020. [CrossRef]

21. Akar, S.; Erdoğdu, M.M. Syrian Refugees in Turkey and Integration Problem Ahead. J. Int. Migr. Integr. 2019, 20, 925-940. [CrossRef]

22. African Union. Agenda 2063: The Africa We Want. In Proceedings of the2020 Conference Paper 2, Addis Ababa, Ethiopia, 17-19 May 2015.

23. Dare, O.; Abebe, A.M. Regional Solutions and the Global Compact on Refugees: The Experience from Africa. Int. J. Refug. Law 2018, 30, 704-706. [CrossRef]

24. Braithwaite, A.; Chu, T.S.; Curtis, J.; Ghosn, F. Violence and the perception of risk associated with hosting refugees. Public Choice 2019, 178, 473-492. [CrossRef]

25. UNHCR. Implementing a Comprehensive Refugee Response: The Zambia Experience; UNHCR: Copenhagen, Denmark, 2019; Available online: https:/ / globalcompactrefugees.org/sites/default/files/2019-12/Zambia\%20CRRF\%20Best\%20Practices\%20Report_ FINAL.PDF (accessed on 30 January 2021).

26. UNHCR. UNHCR Chief Applauds Zambia's Openness to Refugees; UNHCR: Lusaka, Zambia, 2019; Available online: https://www.unhcr.org/news/latest/2019/10/5daa1d494/unhcr-chief-applauds-zambias-openness-refugees.html (accessed on 30 January 2021).

27. Ager, A.; Strang, A. Understanding Integration: A Conceptual Framework. J. Refug. Stud. 2008, 21, 166-191. [CrossRef]

28. Penninx, R.; Garcés-Mascareñas, B. The Concept of Integration as an Analytical Tool and as a Policy Concept. In Integration Processes and Policies in Europe; Garcés-Mascareñas, B., Penninx, R., Eds.; Springer: Berlin/Heidelberg, Germany, 2016.

29. Herreros, F.; Criado, H. Social Trust, Social Capital and Perceptions of Immigration. Political Stud. 2009, 57, 337-355. [CrossRef]

30. Greussing, E.; Boomgaarden, H.G. Shifting the refugee narrative? An automated frame analysis of Europe's 2015 refugee crisis. J. Ethn. Migr. Stud. 2017, 43, 1749-1774. [CrossRef]

31. McKay, F.H.; Thomas, S.L.; Kneebone, S. 'It Would be Okay If They Came through the Proper Channels': Community Perceptions and Attitudes toward Asylum Seekers in Australia. J. Refug. Stud. 2012, 25, 113-133. [CrossRef]

32. Stephan, W.G.; Renfro, C.L. The role of threat in intergroup relations. In From Prejudice to Intergroup Emotions: Differentiated Reactions to Social Groups; Mackie, D.M., Smith, E.R., Eds.; Psychology Press: New York, NY, USA, 2002; pp. $191-207$.

33. Stephan, W.G.; Stephan, C.W. An integrated threat theory of prejudice. In Reducing Prejudice and Discrimination; Oskamp, S., Ed.; Psychology Press: Mahwah, NJ, USA, 2000; pp. 23-45; ISBN 9781135662011.

34. Bobo, L. Whites' opposition to busing: Symbolic racism or realistic group conflict? J. Pers. Soc. Psychol. 1983, 45, 1196-1210. [CrossRef]

35. Jackson, J.W. Realistic group conflict theory: A review and evaluation of the theoretical and empirical literature. Psychol. Rec. 1993, 43, 395-413.

36. Schlueter, E.; Davidov, E. Contextual Sources of Perceived Group Threat: Negative Immigration-Related News Reports, Immigrant Group Size and their Interaction, Spain 1996-2007. Eur. Sociol. Rev. 2013, 29, 179-191. [CrossRef]

37. Weber, H. National and regional proportion of immigrants and perceived threat of immigration: A three-level analysis in Western Europe. Int. J. Comp. Sociol. 2015, 56, 116-140. [CrossRef]

38. MacDonald, F. Positioning young refugees in Australia: Media discourse and social exclusion. Int. J. Incl. Educ. 2017, 21, 1182-1195. [CrossRef]

39. Böhmelt, T.; Bove, V.; Gleditsch, K.S. Blame the victims? Refugees, state capacity, and non-state actor violence. J. Peace Res. 2019, 56, 73-87. [CrossRef]

40. Çirakoğlu, O.C.; Demirutku, K.; Karakaya, O. The Mediating Role of Perceived Threat in the Relationship between Casual Contact and Attitudes towards Refugees in Turkey. J. Refug. Stud. 2020. [CrossRef]

41. Fisk, K. Camp settlement and communal conflict in sub-Saharan Africa. J. Peace Res. 2019, 56, 58-72. [CrossRef]

42. McLaren, L.M. Anti-Immigrant Prejudice in Europe: Contact, Threat Perception, and Preferences for the Exclusion of Migrants. Soc. Forces 2003, 81, 909-936. [CrossRef]

43. Sides, J.; Citrin, J. European Opinion about Immigration: The Role of Identities, Interests and Information. Br. J. Polit. Sci. 2007, 37, 477-504. [CrossRef]

44. Baez, J.E. Civil wars beyond their borders: The human capital and health consequences of hosting refugees. J. Dev. Econ. 2011, 96, 391-408. [CrossRef]

45. Mabiso, A.; Maystadt, J.-F.; Vandercasteelen, J.; Hirvonen, K. Refugees, Food Security, and Resilience in Host Communities: Transitioning from Humanitarian Assistance to Development of Protracted Refugee Situations; International Food Policy Research Institute (IFPR): Washington, DC, USA, 2014.

46. Bansak, K.; Hainmueller, J.; Hangartner, D. How economic, humanitarian, and religious concerns shape European attitudes toward asylum seekers. Science 2016, 354, 217-222. [CrossRef]

47. Mencutek, Z.S.; Nashwan, A.J. Perceptions about the Labor Market Integration of Refugees: Evidences from Syrian Refugees in Jordan. J. Int. Migr. Integr. 2021, 22, 615-633. [CrossRef] 
48. Coenders, M.; Scheepers, P. Changes in Resistance to the Social Integration of Foreigners in Germany 1980-2000: Individual and Contextual Determinants. J. Ethn. Migr. Stud. 2008, 34, 1-26. [CrossRef]

49. Kuntz, A.; Davidov, E.; Semyonov, M. The dynamic relations between economic conditions and anti-immigrant sentiment: A natural experiment in times of the European economic crisis. Int. J. Comp. Sociol. 2017, 58, 392-415. [CrossRef]

50. Valtonen, K. From the Margin to the Mainstream: Conceptualizing Refugee Settlement Processes. J. Refug. Stud. 2004, 17, 70-96. [CrossRef]

51. Allport, G.W.; Clark, K.; Pettigrew, T. The Nature of Prejudice; Addison-Wesley Publishing Company: Cambridge, MA, USA, 1954.

52. Pettigrew, T.F. Intergroup Contact Theory. Annu. Rev. Psychol. 1998, 49, 65-85. [CrossRef]

53. Pettigrew, T.F.; Tropp, L.R. A meta-analytic test of intergroup contact theory. J. Pers. Soc. Psychol. 2006, 90, 751-783. [CrossRef] [PubMed]

54. Crawley, H.; Drinkwater, S.; Kausar, R. Attitudes towards asylum seekers: Understanding differences between rural and urban areas. J. Rural Stud. 2019, 71, 104-113. [CrossRef]

55. Fajth, V.; Bilgili, Ö.; Loschmann, C.; Siegel, M. How do refugees affect social life in host communities? The case of Congolese refugees in Rwanda. Comp. Migr. Stud. 2019, 7, 33. [CrossRef]

56. Alloush, M.; Taylor, J.E.; Gupta, A.; Rojas Valdes, R.I.; Gonzalez-Estrada, E. Economic Life in Refugee Camps. World. Dev. 2017, 95, 334-347. [CrossRef]

57. Loschmann, C.; Bilgili, Ö.; Siegel, M. Considering the benefits of hosting refugees: Evidence of refugee camps influencing local labour market activity and economic welfare in Rwanda. IZA J. Dev. Migr. 2019, 9, 5. [CrossRef]

58. Vemuru, V.; Sarkar, A.; Fitri Woodhouse, A. Impact of Refugees on Hosting Communities in Ethiopia: A Social Analysis; World Bank: Washington, DC, USA, 2020.

59. Larmer, M. At the Crossroads: Mining and Political Change on the Katangese-Zambian Copperbelt; Oxford University Press: Oxford, $\mathrm{UK}, 2016$.

60. Clark, J.F. The African Stakes of the Congo War; Palgrave Macmillan: New York, NY, USA, 2002; ISBN 9781403982445.

61. Vlassenroot, K.; Verweijen, J. Democratic Republic of Congo: The Democratization of Militarized Politics. In Africa's Insurgents. Navigating an Evolving Landscape; Bøås, M., Dunn, K., Eds.; Lyenne Rienner: Boulder, CO, USA, 2017 ; pp. 99-118.

62. Mkandawire, S.B.; Daka, H. Cultural Preservation Literacy in Zambia: A Case Study of the Lala People of Serenje District. Multidiscip. J. Lang. Soc. Sci. Educ. 2018, 1, 139-174.

63. Devictor, X.; Do, Q.-T.; Levchenko, A.A. The globalization of refugee flows. J. Dev. Econ. 2021, 150, 102605. [CrossRef]

64. Mofya-Mukaka, R.; Sambo, J.; Kuhlgatz, C.H. Exploring Linkages between Farm Productive Assets and Household Food Security in Zambia; Working Paper 124; Inaba Agricultural Policy Research Institute: Lusaka, Zambia, 2017; Available online: https://www.researchgate.net/profile/rhoda_mofya/publication/322593322_exploring_linkages_between_farm_productive_ assets_and_household_food_security_in_zambia (accessed on 2 June 2021).

65. Central Statistical Office. 2017 Labour Force Survey Report; Ministry of Labour and Social Security: Lusaka, Zambia, 2018. Available online: https:/ / www.zamstats.gov.zm/phocadownload/Labour/2017\%20Labour\%20Force\%20Survey\%20Report.pdf (accessed on 4 June 2021).

66. Gronau, S.; Hadersdorfer, J.; Nöldeke, B.; Petrusjanz, N.; Stützel, H.; Winter, E. Ernährungssicherheit im ländlichen Sambia; Ernährung im Fokus-02; Bundesanstalt für Landwirtschaft und Ernährung (BLE): Bonn, Germany, 2019; Zeitschrift für Fach-, Lehr- und Beratungskräfte, Artikel-Nr. 5982, ISSN 1617-4518.

67. Nöldeke, B.; Winter, E.; Grote, U. Seed Selection Strategies for Information Diffusion in Social Networks: An Agent-Based Model Applied to Rural Zambia. J. Artif. Soc. Soc. Simul. 2020, 23, 1-9. [CrossRef]

68. Stevenson, J.C.; Pinchoff, J.; Muleba, M.; Lupiya, J.; Chilusu, H.; Mwelwa, I.; Mbewe, D.; Simubali, L.; Jones, C.M.; Chaponda, M.; et al. Spatio-temporal heterogeneity of malaria vectors in northern Zambia: Implications for vector control. Parasites Vectors 2016, 9, 510. [CrossRef] [PubMed]

69. Gronau, S.; Winter, E.; Grote, U. Papyrus, Forest Resources and Rural Livelihoods: A Village Computable General Equilibrium Analysis from Northern Zambia. Nat. Resour. 2018, 9, 268-296. [CrossRef]

70. UNHCR. Mantapala Settlement Briefing Note, September 2020, Lusaka, Zambia; UNHCR: Lusaka, Zambia, 2020; Available online: https://reliefweb.int/report/zambia/mantapala-refugee-settlement-briefing-note-september-2020 (accessed on 29 January 2021).

71. UNHCR. Zambia: Refugees' Livelihoods and Economic Inclusion July 2019; UNHCR: Lusaka, Zambia, 2019; Available online: https:/ / reliefweb.int/report/zambia/zambia-refugees-livelihoods-and-economic-inclusion-july-2019 (accessed on 1 June 2021).

72. Govt. Zambia; UNHCR. Event Report: Launch of the Zambia Chapter of the Regional Refugee Response Plan (RRRP) for the Democratic Republic of Congo (DRC) Situation; UNHCR: Lusaka, Zambia, 2018; Available online: https:/ / reliefweb.int/report/zambia/eventreport-launch-zambia-chapter-regional-refugee-response-plan-rrrp-democratic (accessed on 4 June 2021).

73. Abdelaaty, L.; Steele, L.G. Explaining Attitudes Toward Refugees and Immigrants in Europe. Political Stud. 2020, 003232172095021. [CrossRef]

74. Bundervoet, T. Livestock, Land and Political Power: The 1993 Killings in Burundi. J. Peace Res. 2009, 46, 357-376. [CrossRef]

75. Do, T.L.; Nguyen, T.T.; Grote, U. Livestock production and income inequality in rural Vietnam. Empir. Econ. 2021, 1-30. [CrossRef]

76. FAO. The State of World Fisheries and Aquaculture 2020: Sustainability in Action; FAO: Rome, Italy, 2020. 
77. FAO. Sustainable Woodfuel for Food Security: A Smart Choice: Green, Renewable and Affordable; FAO: Rome, Italy, 2017; Available online: https:/ / research.wur.nl/en/publications/sustainable-woodfuel-for-food-security-a-smart-choice-green-renew (accessed on 1 June 2021).

78. Unser, A.; Ziebertz, H.-G. The Impact of Religion and National Origin on Attitudes towards Refugee Rights: An International Comparative Empirical Study. Religions 2020, 11, 303. [CrossRef]

79. Rustenbach, E. Sources of Negative Attitudes toward Immigrants in Europe: A Multi-Level Analysis. Int. Migr. Rev. 2010, 44, 53-77. [CrossRef]

80. Long, J.S.; Freese, J. Regression Models for Categorical Dependent Variables Using Stata, 2nd ed.; State Press: College Station, TX, USA, 2006; ISBN 9781597180115.

81. Rayton, B.A. Examining the interconnection of job satisfaction and organizational commitment: An application of the bivariate probit model. Int. J. Hum. Resour. Manag. 2006, 17, 139-154. [CrossRef]

82. Greene, W.H. Econometric Analysis, 5th ed.; Prentice Hall: Upper Saddle River, NJ, USA, 2003.

83. Greene, W.H. Marginal Effects in the Bivariate Probit Model; New York University: New York, NY, USA, 1996; NYU Working Paper No. EC-96-11.

84. Masiero, L.; Zoltan, J. Tourists intra-destination visits and transport mode: A bivariate probit model. Ann. Tour. Res. 2013, 43, 529-546. [CrossRef]

85. Morais, F.; Serrasqueiro, Z.; Ramalho, J.J. The zero-leverage phenomenon: A bivariate probit with partial observability approach. Res. Int. Bus. Financ. 2020, 53, 101201. [CrossRef]

86. Neter, J.; Wassermann, W.; Kutner, M.H. Applied Linear Regression Models; Richard D. Irwin, Inc.: Homewood, IL, USA, 1983.

87. Ditekemena, J.D.; Nkamba, D.M.; Mutwadi, A.; Mavoko, H.M.; Siewe Fodjo, J.N.; Luhata, C.; Obimpeh, M.; van Hees, S.; Nachega, J.B.; Colebunders, R. COVID-19 Vaccine Acceptance in the Democratic Republic of Congo: A Cross-Sectional Survey. Vaccines 2021, 9, 153. [CrossRef]

88. Bilgili, Ö.; Loschmann, C.; Fransen, S.; Siegel, M. Is the Education of Local Children Influenced by Living near a Refugee Camp? Evidence from Host Communities in Rwanda. Int. Migr. 2019, 57, 291-309. [CrossRef]

89. Chambers, R. Hidden Losers? The Impact of Rural Refugees and Refugee Programs on Poorer Hosts. Int. Migr. Rev. 1986, 20, 245-263. [CrossRef] [PubMed]

90. Gengo, R.G.; Oka, R.C.; Vemuru, V.; Golitko, M.; Gettler, L.T. Positive effects of refugee presence on host community nutritional status in Turkana County, Kenya. Am. J. Hum. Biol. 2018, 30. [CrossRef] [PubMed]

91. Tafere, M. Forced displacements and the environment: Its place in national and international climate agenda. J. Environ. Manag. 2018, 224, 191-201. [CrossRef]

92. Crisp, R.J.; Turner, R.N. Can imagined interactions produce positive perceptions? Reducing prejudice through simulated social contact. Am. Psychol. 2009, 64, 231-240. [CrossRef] [PubMed] 